\title{
Compiling national accounts, balance- of-payments and foreign trade statistics in the framework of the coronavirus disease (COVID-19) health emergency
}

\section{Executive summary}

In the context of the global coronavirus disease (COVID-19) pandemic, the Economic Commission for Latin America and the Caribbean (ECLAC) is preparing a series of short publications with relevant policy recommendations for this period. This note includes several recommendations for the continued collection of information linked to national accounts, balance-of-payments and foreign trade statistics.

\section{Introduction}

This document was prepared by the Statistics Division of the Economic Commission for Latin America and the Caribbean (ECLAC) on the basis of two videoconferences held with representatives of Latin American countries on 15 and 22 April 2020, ${ }^{1}$ as well as exchanges with regional experts. ${ }^{2}$ Statistical work is not immune to the challenges arising from the COVID-19 health emergency, so the practices developed by countries and the international statistical community are crucial for overcoming the obstacles to measuring the impact of this pandemic. In this context, it should be borne in mind that this issue is evolving continuously and should be reviewed as experiences are shared and progress is made on measurement proposals, so that some of the proposals presented here can be adjusted or expanded in order to better reflect reality.

As a result of the health emergency caused by the COVID-19 pandemic, the countries of the region have declared states of emergency and applied measures to restrict economic and social activity, which affect the compilation of basic statistics. In this context, ECLAC, through its Statistics Division and making use of the Knowledge Transmission Network of the Statistical Conference of the Americas of ECLAC, has decided to conduct a survey of the situation to determine the effects that the health emergency is having on statistical institutions' work. To this end, the Division has launched a series of surveys and held videoconferences with representatives of the national statistical offices (NSOs) and central banks of the countries of the region, and international organizations, as well as experts and consultants. Until now, the focus has been on social and price statistics (in particular, consumer prices). This document addresses the effects of the crisis on the compilation of economic statistics, in particular those on national accounts, the balance of payments and foreign trade, focusing on the aspects related information sources, compilation methods and the dissemination of press releases

Representatives of the National Institute of Statistics and Censuses (INDEC) of Argentina, the Central Bank of Ecuador, the Bank of Guatemala, the Central Bank of the Dominican Republic, the National Institute of Statistics and Geography (INEGI) of Mexico, the Bank of Mexico and the Central Bank of Uruguay participated in the first videoconference. Representatives of all the Latin American countries were invited to participate in the second videoconference.

Lourdes Erro, Salvador Marconi and Juan Carlos Propatto
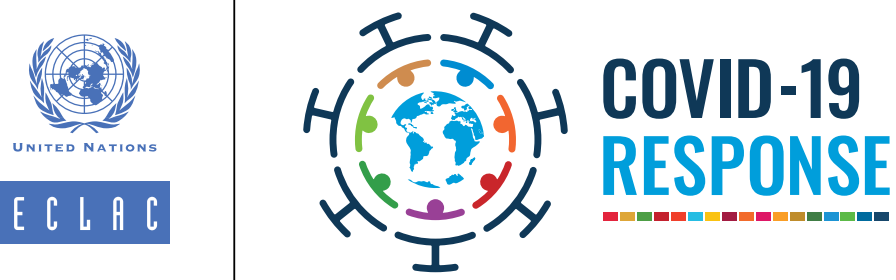

Executive summary

Introduction

A. Information sources

B. Compilation methods

C. Dissemination

Bibliography

Annex 1

Annex 2

Annex 3 
This document seeks to provide information about the state of affairs in Latin America, and to disseminate some of the recommendations to address the COVID-19 pandemic discussed with the countries in relation to the compilation of national accounts, balanceof-payments and foreign trade statistics. The recommendations are based on international manuals and guidelines that the countries themselves consider to be the most appropriate. More emphasis has been placed on monthly and quarterly frequency calculations than on annual ones.

This is the first document on this subject, since over time it is likely that new situations will arise that will warrant an update.

\section{A. Information sources}

The information sources have been divided into three main groups, each with different problems: business economic surveys; administrative records; and other sources.

To date, there have been no serious problems in terms of basic statistical data collection. However, coverage and non-response problems are expected to increase substantially in the coming months. In general, the information sources needed to compile balance-of-payments and foreign trade statistics are more readily available than those for national accounts.

\section{Business economic surveys}

- Survey modality. Given the current restrictions on interviewers' movements and the impossibility of carrying out surveys face-to-face, online surveys are more likely to be completed by respondents.

- Non-responses. Non-responses to business surveys are increasingly likely, which may be caused by very different situations, such as: (i) the company is operational, but has not responded, for various reasons; (ii) the company has closed down temporarily; or (iii) the company has been forced to close down permanently.

- Change in the production basket. Some companies have modified their production baskets, converting their usual production line to products that are in high demand as a result of the pandemic, such as masks, special clothing, rubbing alcohol and respirators. It should be ascertained whether economic surveys are capturing these production basket changes (which may require different technology and, consequently, lead to changes in production costs and functions).

- Use of web applications. The use of free or paid Internet applications has become widespread very quickly, as a replacement for the face-to-face supply of some products and services, ${ }^{3}$ and due to the development of online communications and sales. To the extent that surveys capture sales through different channels, it is assumed that this substitution effect is being captured. However, steps must be taken to verify with the companies providing the virtual services the coverage of these sales and whether the surveys capture output linked to online transactions.

\section{Administrative records}

- Confidentiality of tax information. The availability of information is severely limited by the fact that NSOs and central banks are unable to access tax, and social security and social insurance databases, because of existing legislation or long-standing institutional issues.

- Measures to defer tax obligations and social security contributions. These measures include postponing the payment date, the deadline for tax returns and/or the submission of companies' financial statements and balance sheets. This affects the timeliness of the information, causing delays in the reception of tax information, as well as the data used to estimate the associated variables in the national accounts, such as purchases, sales, financial statements or balance sheets.

\footnotetext{
3 For example, streaming services.
} 
- Foreign trade records. In general, there are no issues with these records, except for some minor delays in both the receipt of information and the entry of products into the countries owing to stricter customs controls. According to the country consultations carried out by ECLAC, customs authorities remain operational, even with a reduced staff. The percentage of imputations has increased, albeit slightly.

- Migration records. In general, there are no issues with these records.

\section{Other information}

- Construction surveys and agriculture and livestock surveys. As these surveys are carried out in the field (either at the building site or the farming establishment) it is very difficult to get a response by telephone. They are affected by restrictions on the movements of interviewers.

- International tourism surveys. These are carried out face-to-face. It was possible to collect the information in some countries, while the surveys had to be cancelled in others. It is likely that the number of cancellations of these operations will increase in the coming months, given the closure of borders and the almost total collapse of tourist flows.

- Business tendency surveys. In some cases, delays in the receipt of responses have been reported.

\section{Recommendations}

- Promote the adoption of online or telephone surveys.

- Assess companies' non-responses carefully to determine the cause, establishing whether it is a non-response because of a failure to comply with the deadlines, or because of the temporary or permanent closure of the company. Assess in each case whether or not it is appropriate to impute or substitute missing data. ${ }^{4}$ Companies' location should be taken into account in the assessment, as some of the most affected cities or areas in the countries of the region may have been completely closed down.

- Take high-level action to support efforts to address the legal or institutional limitations that prevent NSOs and central banks accessing the administrative databases of tax or social insurance or security systems. Under normal circumstances, these administrative records help to supplement or even replace missing information for some industries. In the current crisis they are even more important, given the aforementioned limitations of the usual statistical survey methods that make it difficult to capture the income, expenditure and employment data of economic units. Legal or institutional obstacles that prevent NSOs and central banks from accessing fiscal and social security information sources, or the existence of data access barriers between those institutions, can affect the quality of the country's economic statistics.

- Promote and strengthen links with business chambers or associations, relevant government ministries ${ }^{5}$ and experts familiar with how certain industries in the country work, in order to also have a qualitative opinion on the evolution of the most important product markets. ${ }^{6}$

- Consult the economic press, which usually carries interviews with business and business associations leaders. Obviously, this information must be analysed carefully because of the biases usually present in the opinions expressed by these leaders in the current situation, in order to have greater access to lines of credit from financial institutions or to State subsidies

- Follow up with those companies that have restructured their production basket to meet the demand for supplies related to the health emergency.

- Compile information in a table to determine the percentage of imputations made in relation to GDP, considering the sources used for value, price and volume indicators at

$4 \quad$ Under normal circumstances, missing data are usually imputed by taking the averages of the same branch and stratum or of the closest neighbouring companies, or by using moving averages. The plausibility of using imputed data at the present time should be assessed.

For example, the ministries covering tourism, health, education and transport

6 Qualitative data may also include, for example, figures illustrating sales' trends or business development. 
the most granular level of products or industries. This should make it easier to identify problems associated with the sources and their weighting, by coding imputations in order to pinpoint those carried out during the crisis, and by incorporating production basket changes made in response to the situation. An example of such a table is given in annex 1.

\section{B. Compilation methods}

Below are some questions about the estimation methods used or economic transactions which should be addressed.

\section{Output of collective and individual government services}

- The measurement of output, intermediate consumption and compensation at current prices is supported by data from the government budget, ${ }^{7}$ using the sum-of-costs method (input method) to measure output. In the context of the restrictions imposed, some services have been discontinued and employees are quarantined and unable to provide any services; however, the government has continued to pay wages and salaries and purchase goods and services to be used as inputs.

- In some countries, the measurement of the volume of output or value added is based on the total number of jobs (the labour input method). This method does not capture productivity. At the present time, some public services have increased their output in terms of volume (for example, health services linked to care during the pandemic or security services); others have seen their activity decrease (for example, other non-essential health services) or their working modality changed (such as education or other services, which are being carried out online or remotely); and others may have been cancelled (some justice and administrative services for example). The measures recommended for quantifying output volume that are based on the supply of products (output method), rather than on inputs, — such as teaching hours received by students, health treatments broken down by type of illness according to their costs, or number of services provided by public administrations - are difficult to apply in practice at the moment in some countries owing to the lack of information.

\section{Output of non-financial market companies ${ }^{8}$}

- Some companies had to close down temporarily so their output is zero and their employees have not carried out any tasks linked to the production process. However, certain companies have continued to compensate employees. In addition, some have received government subsidies to cover part of the compensation bill and/or to support production.

\section{Financial companies' output}

- The banks have implemented policies to extend the deadlines for the payment of loan installments and interest, making the parameters for default more flexible and offering loans with subsidized interest rates, among other measures. These measures have an impact on accrual-based records, as obligations continue to be incurred but payments (in cash) are postponed and reflected in the financial statements and balance sheets of the financial institutions, as well as in the output of financial intermediation services indirectly measured (FISIM). The central banks of some countries have implemented subsidized credit programmes, while others have set ceilings on the interest rates paid on fixed installments. Some banking services have also been temporarily suspended or are limited, while at the same time electronic transactions have multiplied, all of which will be reflected in the sector's output.

\section{Questions}

- Physical flow of goods method. This method is used in some countries to measure trade and freight transportation. However, inventory changes are not taken into account

\footnotetext{
Preferably budget implementation information. Non-financial corporations and household producers.
} 
because of a lack of information, but in the current situation it can be assumed that inventory volumes are changing significantly. ${ }^{9}$

- Price indices. The consumer and producer price indices for the month of March included a higher proportion of imputations, particularly for the goods and services most affected by the restrictions, such as leisure services.

- Linear demand function method. Some countries estimate output volume, particularly for personal services, such as hairdressing or restaurants, which are based on the application of a linear demand function that incorporates price and income elasticity values, calculated on the basis of household income and expenditure surveys. These estimates should be reconsidered and their individual elements, such as relative price and actual revenue, evaluated in order for the result to be acceptable.

- Telecommunications services. An increase in the volume of activity of these services has been recorded, owing to the substitution effect on consumers' data use, resulting from teleworking or online shopping. Service prices or rates may also be changed.

- Seasonal adjustment and trend-cycle estimation. In the presence of a very strong irregular component, these adjustments may make it difficult to measure series adjusted for seasonality and trend-cycle variation, as the filters used cannot correctly isolate that component.

- Disaggregation of the observed and non-observed economy. The evolution of the non-observed economy is based on in-depth analysis of coefficients for the baseline or reference year, which, under normal conditions, should be updated by the results of studies and special household surveys, and supplemented by employment surveys.

\section{Recommendations}

- Identify the fiscal policies implemented by the government to detect economic transactions and record them in accordance with the System of National Accounts 2008 (2008 SNA) and in the balance of payments, where applicable. Examples of such policies include reallocating budget items, providing subsidies to producer companies ${ }^{10}$ and households ${ }^{11}$ and relaxing fiscal obligations. Analysis of the impact of the support measures implemented by the government is presented in annex 3 .

- Record government subsidies to producer companies ${ }^{12}$ as other subsidies on production (D39) ${ }^{1314}$ Record production as zero for those market companies that have been closed down temporarily during the crisis without the possibility of switching to alternative sales and production channels. If such companies continue to incur expenses, either for inputs or for the compensation of employees, these are recorded as transactions and the losses are recorded under gross operating surplus or gross mixed income..$^{15}$

- Impute other subsidies on production (D39) under the measurement of output and value added of collective and individual government services valued at current prices whose supply has been severely restricted (United Nations, 2020, paragraph 36). To this end the sum-of-costs formula recommended by the 2008 SNA must continue to be used, but incorporating this imputation as a subsidy on production with a negative sign. In a worst-case scenario, if the service has been totally suspended, the output and value added that is accounted for is equal to zero, since the value of the other subsidies on production is equivalent to the sum of the costs, always with a negative sign. The existence of subsidies payable and receivable within the government sector itself is contemplated in situations where there are subsidies "applicable to all producers" (IMF, 2014, paragraph 6.86), which is the case in the current situation. A numerical example of the proposed record is given in annex 2 .

\footnotetext{
Import records are one example mentioned by some countries, which are part of the product supply flow, but there is no information on the accumulation of stocks of these goods.

10 Includes producer companies and households. The subsidy provides an incentive to keep employees on the payroll and helps to ensure business continuity in the future.

Transfers provide social assistance to consumer households

Producer companies and households.

The code used corresponds to the transaction classifications of the System of National Accounts 2008 (2008 SNA) (European Commission and others, 2016).

14 This recommendation is in line with those made in United Nations (2020)

15 Moderated by other subsidies on production.
} 
- Adjust the volume index of collective and individual government services, where measurement is based on the total number of jobs. ${ }^{16}$ The adjustment may be upward (for example, health services) or downward (services affected by complete or partial closures due to quarantine). To make the adjustment, consideration may be given to qualitative information or estimates by service involved on hours worked under normal conditions compared to hours worked in the current situation, on the use and effectiveness of teleworking, on e-learning and/or qualitative adjustments by characteristic. This type of adjustment is encouraged; otherwise, the underlying assumption would be that steps taken to strengthen services affected by the pandemic (such as health services) or to restrict them (other services) have no impact on measuring the volume of output and value added of the services provided by the government. ${ }^{17}$

- Record subsidies on products (D31) in situations where the central bank sets a lower rate of interest than the market rate ${ }^{18}$ and/or taxes on products (D21) resulting from the central bank imposing a higher rate of interest than the market rate (European Commission and others, 2016, para. 7.96(f)). Although it is not one of the options proposed in 2008 SNA, but was part of the discussions prior to its approval, an alternative that could be used at a country's discretion is to consider both situations as other subsidies on production (D39) and/or other taxes on production (D29), based on the proposal of the United Nations document (2006), as well as the recommendations made in the handbook "Financial Production, Flows and Stocks in the System of National Accounts" (United Nations, 2005, paras. 3.115, 3.119 and 3.123).

- Gather information on the variable changes in inventories in cases where the flow of goods method is used, at least for the economy's most important goods and/or for those for which such changes are more significant. If no information is obtained, it is recommended to make imputations that reflect this reality.

- Strengthen the compilation of quarterly supply and use tables in full or at least in part for the country's main products or industries. This allows the most significant discrepancies between the supply and the use of products (and in the production structure) to be detected and to produce plausible, reasonably coherent results. The highest possible level of product detail should be used, so that changes that may occur in value, volume and prices can be evaluated

- Review the breakdown of the imputation coefficients of the non-observed economy. The imputed evolution of the size of the non-observed economy compared to the observed economy for certain branches may be a source of error, since the proportions may have changed substantially at this time. Information from household and employment surveys is used to update the weights of the non-observed economy and also for informal employment. However, it may also be difficult to carry out these surveys because of current restrictions, so their results should be subject to a more critical reading than usual and used with great care. As far as possible, it is also recommended that the coefficients of the non-observed economy be treated differently by industry.

- Incorporate, if it has not been done already, the analysis of information from databases of debit or credit cards and online purchases, among other things, that could be used as a proxy variable for these transactions in the formal economy.

- Assess the possibility of using information from monetary and financial statistics to validate transactions in the real economy, such as consumer credit or mortgage trends.

- Strengthen the role of the sector specialists responsible for calculating the production accounts. The sector specialist should be the person who knows the most about the

16 The 2008 SNA proposes three possible methods of compiling volume estimates of the output of non-market goods and services: derive a pseudo output price index to reflect productivity growth; the output volume method for individual services, based on the calculation of a volume indicator of output using weighted measures; and the input method for collective services, which consists of measuring changes in the weighted sum of volume measures of all the inputs, either by deflating the various input costs by corresponding constant-quality price indices or, alternatively, using volume indicators (for example, number of hours worked by employees).

The growth in the implicit price as a result of hourly compensation is expected to be considerable, most likely higher than usual. Users should be warned that such an increase does not mean higher labour costs, but rather higher hourly wages. Labour costs have not increased because they include the subsidy imputed to payroll. Meanwhile, compensation per job has not increased significantly. In some services, the change in the volume of hours worked (or of adjusted posts) would be downwards, although compensation continues to be paid anyway. For the subtotal of individual services, volume growth may have no impact, owing to the trade-off between the decreasing volume of education services and the increasing volume of medical services

18 See European Commission and others (2016, para. 7.105 (d)). This is the most common situation at the present time. 
particular situation of an industry in the country. Experts' opinions are increasingly important at the present time. A detailed record must be kept of the treatment of sources, the compilation methods and the assumptions made.

- Adopt flexible criteria in terms of the methods used, modifying the estimation method if it is deemed necessary.

- Examine in-depth the price indices that are used as an inflator or deflator, as they may also include higher-than-usual levels of imputation.

- Analyse in greater detail than usual the macroeconomic summary data of the national accounts and the balance of payments, and compare them with public finance statistics, monetary and financial statistics, and data on employment, unemployment and underemployment. The most relevant impacts of the economic situation must be clearly reflected in the national accounts' figures. This requires exhaustive analysis at both the detailed and more aggregate levels, considering the three approaches to estimating GDP and using alternative information sources, such as opinion polls, Internet data, expert opinions and data on the consumption of typical production inputs

\section{Dissemination}

Dissemination schedules are announced in advance and countries have made formal commitments to all users by adopting the International Monetary Fund's data dissemination standards. To date (May 2020), the publication schedules have been respected, although it is possible that in the next few months the dissemination of a statistical product may be postponed if a minimum level of coverage is not attained or necessary information is missing. However, postponing the dissemination of statistics would coincide precisely with more urgent demands for official economic figures than usual.

\section{Recommendations}

- Exhaust all possible options to impute data and carry out alternative analysis before deciding to postpone the dissemination of a statistical product

- Inform users, through detailed explanatory notes, about the restrictions on the availability of basic statistics and the imputation methods used, by industry and type of economic transaction.

- Consider the possibility of grouping together and disseminating in less detail those items that are usually published, if they do not meet the minimum quality level.

- Inform users about the main adjustments made to the working methods of the offices working in this area.

- Warn users in advance if, in a worst-case scenario, it is decided to postpone the release date of a statistical product.

\section{Bibliography}

European Commission and others (2016), System of National Accounts 2008 (ST/ESA/ STAT/SER.F/2/Rev.5), NewYork [online] https://unstats.un.org/unsd/nationalaccount/ docs/sna2008.pdf.

IMF (International Monetary Fund)) (2014), Government Finance Statistics Manual 2014, Washington, D.C.

United Nations (2020), "COVID-19: How to Record Government Support to Employers, Self-employed and Households. Statistical Advice", April [online] https:// statswiki.unece.org/download/attachments/278038679/Recording\%20 of\%20government\%20support\%20to\%20 employers\%20and\%20self-employed. pdf?version $=2 \&$ modificationDate $=15873801976158 a p i=v 2$

(2015), "Financial Production, Flows and Stocks in the System of National Accounts", Studies in methods. Series FNo. 113 Handbook of National Accounting(ST/ESA/STAT/ SER.F/113), New York.

(2006), "Output of central banks" (SNA/M1.06/05), Advisory Expert Group on National Accounts [online] https://unstats.un.org/unsd/nationalaccount/AEG/papers/m4cb.pdf. 


\section{Annex 1}

\section{Table of volume, price and value indicators and their weightings}

It is recommended that a table be prepared on a branch-by-branch and/or product-by-product basis with data from sources used and comments on the source's availability, coverage or other representativeness problems.

Table A1.1

Volume, price and value indicators and weightings

\begin{tabular}{|c|c|c|c|c|c|c|c|c|}
\hline Branch/product & \multicolumn{3}{|c|}{ Value } & \multicolumn{3}{|c|}{ Volume } & \multicolumn{2}{|c|}{ Price } \\
\hline \multicolumn{9}{|l|}{ A.0111 } \\
\hline & & & & & & & & \\
\hline & & & & & & & & \\
\hline
\end{tabular}

Source: Economic Commission for Latin America and the Caribbean (ECLAC).

In light of the foregoing and in an effort to prepare for the situation, it is recommended that the following actions be taken:

- Undertake a branch-by-branch or product-by-product assessment: the percentage of missing sources; which sources will be of a lower quality; and which sources will not reflect the situation correctly.

- Consider whether new sources need to be introduced if the current ones do not paint an accurate picture of the phenomenon, ${ }^{1}$ and carry out the necessary research.

- Concentrate on the cases with the greatest impact.

For example, ascertain whether the increase in home deliveries for various purchases is properly accounted for, or whether the stock of passenger transport vehicles represents the change in passenger transportation output when the number of passengers taking mass transit has decreased. 


\section{Annex 2}

Treatment of government-produced services with and without recording the imputation of other subsidies on production

An exercise is presented on the impact of incorporating the record of other subsidies on production (D39) on the recording of the System of National Accounts 2008.

The exercise involves the output of government services, to the value of 100, corresponding to the payment of compensation (for simplicity). The record without imputation is set out in table A2.1, while the record with the imputation is set out in table A2.2.

Table A2.1

System of National Accounts 2008: current, capital and financial accounts, government output without other subsidies on production

\begin{tabular}{|c|c|c|c|c|c|c|c|c|c|c|c|c|c|c|c|c|c|}
\hline \multirow{2}{*}{ Accounts } & \multirow{2}{*}{ Concepts $^{a}$} & \multicolumn{2}{|c|}{ Central bank } & \multicolumn{2}{|c|}{$\begin{array}{l}\text { Deposit-taking } \\
\text { corporations }\end{array}$} & \multicolumn{2}{|c|}{$\begin{array}{l}\text { Non-financial } \\
\text { corporations }\end{array}$} & \multicolumn{2}{|c|}{ Households } & \multicolumn{2}{|c|}{ General government } & \multicolumn{2}{|c|}{ Total economy } & \multicolumn{2}{|c|}{ Rest of world } & \multicolumn{2}{|c|}{$\begin{array}{l}\text { Goods and } \\
\text { services }\end{array}$} \\
\hline & & Uses & Resources & Uses & Resources & Uses & Resources & Uses & Resources & Uses & Resources & Uses & Resources & Uses & Resources & s Resources & Uses \\
\hline \multirow{2}{*}{$\begin{array}{l}\text { External } \\
\text { balance of } \\
\text { goods and } \\
\text { services }\end{array}$} & $\begin{array}{l}\text { P6 Exports of goods } \\
\text { and services }\end{array}$ & & & & & & & & & & & & & & & & \\
\hline & $\begin{array}{l}\text { P7 Imports of goods } \\
\text { and services }\end{array}$ & & & & & & & & & & & & & & & & \\
\hline \multirow[t]{6}{*}{$\begin{array}{l}\text { Production } \\
\text { account }\end{array}$} & $\begin{array}{l}\text { P13 Gross output } \\
\text { valued at basic prices }\end{array}$ & & & & & & & & & & 100 & & 100 & & & 100 & \\
\hline & $\begin{array}{l}\text { D21-D31 Taxes less } \\
\text { subsidies on products }\end{array}$ & & & & & & & & & & & & 0 & & & & \\
\hline & $\begin{array}{l}\text { P2 Intermediate } \\
\text { consumption }\end{array}$ & & & & & & & & & 0 & & 0 & & & & & \\
\hline & $\begin{array}{l}\text { B1g Value added, gross } \\
\text { at basic prices/ } \\
\text { GDP at market prices }\end{array}$ & & & & & & & & & 100 & & 100 & & & & & \\
\hline & $\begin{array}{l}\text { P51.c Consumption } \\
\text { of fixed capital }\end{array}$ & & & & & & & & & 0 & & 0 & & & & & \\
\hline & $\begin{array}{l}\text { B1n Value added, net, } \\
\text { at basic prices/ } \\
\text { NDP at market prices }\end{array}$ & & & & & & & & & 100 & & 100 & & & & & \\
\hline \multirow[t]{5}{*}{$\begin{array}{l}\text { Generation } \\
\text { of income } \\
\text { account }\end{array}$} & $\begin{array}{l}\text { B1n Value added, net } \\
\text { at basic prices/ } \\
\text { NDP at market prices }\end{array}$ & & & & & & & & & & 100 & & 100 & & & & \\
\hline & $\begin{array}{l}\text { D1 Compensation } \\
\text { of employees }\end{array}$ & & & & & & & & & 100 & & 100 & & & & & \\
\hline & $\begin{array}{l}\text { D21-D31. Taxes less } \\
\text { subsidies on products }\end{array}$ & & & & & & & & & & & 0 & & & & & \\
\hline & $\begin{array}{l}\text { D39 Other subsidies } \\
\text { on production }\end{array}$ & & & & & & & & & & & & & & & & \\
\hline & $\begin{array}{l}\text { B2g Operating surplus, } \\
\text { gross }\end{array}$ & & & & & & & & & 0 & & 0 & & & & & \\
\hline
\end{tabular}




\begin{tabular}{|c|c|c|c|c|c|c|c|c|c|c|c|c|c|c|c|c|c|}
\hline \multirow{2}{*}{ Accounts } & \multirow{2}{*}{ Concepts $^{a}$} & \multicolumn{2}{|c|}{ Central bank } & \multicolumn{2}{|c|}{$\begin{array}{l}\text { Deposit-taking } \\
\text { corporations }\end{array}$} & \multicolumn{2}{|c|}{$\begin{array}{l}\text { Non-financial } \\
\text { corporations }\end{array}$} & \multicolumn{2}{|c|}{ Households } & \multicolumn{2}{|c|}{ General government } & \multicolumn{2}{|c|}{ Total economy } & \multicolumn{2}{|c|}{ Rest of world } & \multicolumn{2}{|c|}{$\begin{array}{l}\text { Goods and } \\
\text { services }\end{array}$} \\
\hline & & Uses & Resources & Uses & Resources & Uses & Resources & Uses & Resources & Uses & Resources & Uses & Resources & Uses & Resources & 5 Resources & Uses \\
\hline \multirow{3}{*}{$\begin{array}{l}\text { Allocation } \\
\text { of primary } \\
\text { income } \\
\text { account }\end{array}$} & $\begin{array}{l}\text { D1 Compensation } \\
\text { of employees }\end{array}$ & & & & & & & & 100 & & & & 100 & & & & \\
\hline & $\begin{array}{l}\text { D21-D31 Taxes less } \\
\text { subsidies on products }\end{array}$ & & & & & & & & & & & 0 & & & & & \\
\hline & $\begin{array}{l}\text { B5n Balance of } \\
\text { primary income, net/ } \\
\text { National income, net }\end{array}$ & & & & & & & 100 & & 0 & & 100 & & & & & \\
\hline \multirow{2}{*}{$\begin{array}{l}\text { Secondary } \\
\text { distribution } \\
\text { of income } \\
\text { account }\end{array}$} & $\begin{array}{l}\text { B5n Balance of } \\
\text { primary income, net/ } \\
\text { National income, net }\end{array}$ & & & & & & & & 100 & & 0 & & 100 & & & & \\
\hline & $\begin{array}{l}\text { B6n Disposable } \\
\text { income, net/NDP, net }\end{array}$ & & & & & & & 100 & & 0 & & 100 & & & & & \\
\hline \multirow{3}{*}{$\begin{array}{l}\text { Use of } \\
\text { disposable } \\
\text { income } \\
\text { account }\end{array}$} & $\begin{array}{l}\text { B6n Disposable } \\
\text { income, net/NDP, net }\end{array}$ & & & & & & & & 100 & & 0 & & 100 & & & & \\
\hline & $\begin{array}{l}\text { P3 Final consumption } \\
\text { expenditure }\end{array}$ & & & & & & & & & 100 & & 100 & & & & & 100 \\
\hline & $\begin{array}{l}\text { B8n Saving, net/ } \\
\text { National saving, net }\end{array}$ & & & & & & & 100 & & -100 & & 0 & & & & & \\
\hline \multirow{2}{*}{ Accounts } & \multirow{2}{*}{ Concepts } & \multicolumn{2}{|c|}{ Central bank } & \multicolumn{2}{|c|}{$\begin{array}{l}\text { Deposit-taking } \\
\text { corporations }\end{array}$} & \multicolumn{2}{|c|}{$\begin{array}{l}\text { Non-financial } \\
\text { corporations }\end{array}$} & \multicolumn{2}{|c|}{ Households } & \multicolumn{2}{|c|}{ General government } & \multicolumn{2}{|c|}{ Total economy } & \multicolumn{2}{|c|}{ Rest of world } & \multicolumn{2}{|c|}{$\begin{array}{l}\text { Goods and } \\
\text { services }\end{array}$} \\
\hline & & Applications & Origins & Applications & Origins & Applications & Origins & Applications & Origins & Applications & s Origins & Applications & Origins & Applications & Origins & Resources & Uses \\
\hline \multirow[t]{2}{*}{$\begin{array}{l}\text { Capital } \\
\text { account }\end{array}$} & $\begin{array}{l}\text { B8n Saving, net/ } \\
\text { National saving, net }\end{array}$ & & & & & & & & 100 & & -100 & & 0 & & & & \\
\hline & $\begin{array}{l}\text { B9 Net lending/ } \\
\text { net borrowing }\end{array}$ & & & & & & & 100 & & -100 & & 0 & & & & & \\
\hline \multirow[t]{4}{*}{$\begin{array}{l}\text { Financial } \\
\text { account }\end{array}$} & $\begin{array}{l}\text { B9 Net lending/ } \\
\text { net borrowing }\end{array}$ & & & & & & & & 100 & & -100 & & 0 & & & & \\
\hline & $\begin{array}{l}\text { F22 Government } \\
\text { current account } \\
\text { deposits in the } \\
\text { central bank }\end{array}$ & & -100 & & & & & & & -100 & & -100 & -100 & & & & \\
\hline & $\begin{array}{l}\text { F22 Households' } \\
\text { accounts in savings } \\
\text { banks }\end{array}$ & & & & 100 & & & 100 & & & & 100 & 100 & & & & \\
\hline & F21 Bank reserves & & 100 & 100 & & & & & & & & 0 & 0 & & & & \\
\hline
\end{tabular}

Source: European Commission and others, System of National Accounts 2008 (ST/ESA/STAT/SER.F/2/Rev.5), New York, 2016 [online] https://unstats.un.org/unsd/nationalaccount/ docs/sna2008.pdf

The code used corresponds to the transaction classifications of the System of National Accounts 2008 
Table A2.2

System of National Accounts 2008: current, capital and financial accounts, government output with other subsidies on production

\begin{tabular}{|c|c|c|c|c|c|c|c|c|c|c|c|c|c|c|c|c|c|}
\hline \multirow{2}{*}{ Accounts } & \multirow[t]{2}{*}{ Concepts $^{a}$} & \multicolumn{2}{|c|}{ Central bank } & \multicolumn{2}{|c|}{$\begin{array}{l}\text { Deposit-taking } \\
\text { corporations }\end{array}$} & \multicolumn{2}{|c|}{$\begin{array}{l}\text { Non-financial } \\
\text { corporations }\end{array}$} & \multicolumn{2}{|c|}{ Households } & \multicolumn{2}{|c|}{ General government } & \multicolumn{2}{|c|}{ Total economy } & \multicolumn{2}{|c|}{ Rest of world } & \multicolumn{2}{|c|}{ Goods and services } \\
\hline & & Uses & Resources & Uses & Resources & Uses & Resources & Uses & Resources & Uses & Resources & Uses & Resources & Uses & Resources & Resources & Uses \\
\hline \multirow{2}{*}{$\begin{array}{l}\text { Foreign } \\
\text { goods and } \\
\text { services } \\
\text { account }\end{array}$} & $\begin{array}{l}\text { P6 Exports of goods } \\
\text { and services }\end{array}$ & & & & & & & & & & & & & & & & \\
\hline & $\begin{array}{l}\text { P7 Imports of goods } \\
\text { and services }\end{array}$ & & & & & & & & & & & & & & & & \\
\hline \multirow[t]{6}{*}{$\begin{array}{l}\text { Production } \\
\text { account }\end{array}$} & $\begin{array}{l}\text { P13 Gross production } \\
\text { value at basic prices }\end{array}$ & & & & & & & & & & 0 & & 0 & & & 0 & \\
\hline & $\begin{array}{l}\text { D21-D31 Taxes less } \\
\text { subsidies on products }\end{array}$ & & & & & & & & & & & & 0 & & & & \\
\hline & $\begin{array}{l}\text { P2 Intermediate } \\
\text { consumption }\end{array}$ & & & & & & & & & 0 & & 0 & & & & & \\
\hline & $\begin{array}{l}\text { B1g Value added, } \\
\text { gross, at basic prices/ } \\
\text { GDP at market prices }\end{array}$ & & & & & & & & & 0 & & 0 & & & & & \\
\hline & $\begin{array}{l}\text { P51c Consumption } \\
\text { of fixed capital }\end{array}$ & & & & & & & & & 0 & & 0 & & & & & \\
\hline & $\begin{array}{l}\text { B1n Value added, net, } \\
\text { at basic prices/ } \\
\text { NDP at market prices }\end{array}$ & & & & & & & & & 0 & & 0 & & & & & \\
\hline \multirow[t]{5}{*}{$\begin{array}{l}\text { Generation } \\
\text { of income } \\
\text { account }\end{array}$} & $\begin{array}{l}\text { B1n Value added, } \\
\text { net at basic prices/ } \\
\text { NDP at market prices }\end{array}$ & & & & & & & & & & 0 & & 0 & & & & \\
\hline & $\begin{array}{l}\text { D1 Compensation } \\
\text { of employees }\end{array}$ & & & & & & & & & 100 & & 100 & & & & & \\
\hline & $\begin{array}{l}\text { D21-D31 Taxes less } \\
\text { subsidies on products }\end{array}$ & & & & & & & & & & & 0 & & & & & \\
\hline & $\begin{array}{l}\text { D39 Other subsidies } \\
\text { on production }\end{array}$ & & & & & & & & & -100 & & -100 & & & & & \\
\hline & $\begin{array}{l}\text { B2g Operating surplus, } \\
\text { gross }\end{array}$ & & & & & & & & & 0 & & 0 & & & & & \\
\hline \multirow{4}{*}{$\begin{array}{l}\text { Allocation } \\
\text { of primary } \\
\text { income } \\
\text { account }\end{array}$} & $\begin{array}{l}\text { D1 Compensation } \\
\text { of employees }\end{array}$ & & & & & & & & 100 & & & & 100 & & & & \\
\hline & $\begin{array}{l}\text { D21-D31 Taxes less } \\
\text { subsidies on products }\end{array}$ & & & & & & & & & & & 0 & & & & & \\
\hline & $\begin{array}{l}\text { D39 Other subsidies } \\
\text { on production }\end{array}$ & & & & & & & & & & -100 & & -100 & & & & \\
\hline & $\begin{array}{l}\text { B5n Balance of primary } \\
\text { income, net/ } \\
\text { National income, net }\end{array}$ & & & & & & & 100 & & -100 & & 0 & & & & & \\
\hline
\end{tabular}




\begin{tabular}{|c|c|c|c|c|c|c|c|c|c|c|c|c|c|c|c|c|c|}
\hline \multirow[t]{2}{*}{ Accounts } & \multirow[t]{2}{*}{ Concepts $^{a}$} & \multicolumn{2}{|c|}{ Central bank } & \multicolumn{2}{|c|}{$\begin{array}{l}\text { Deposit-taking } \\
\text { corporations }\end{array}$} & \multicolumn{2}{|c|}{$\begin{array}{l}\text { Non-financial } \\
\text { corporations }\end{array}$} & \multicolumn{2}{|c|}{ Households } & \multicolumn{2}{|c|}{ General government } & \multicolumn{2}{|c|}{ Total economy } & \multicolumn{2}{|c|}{ Rest of world } & \multicolumn{2}{|c|}{ Goods and services } \\
\hline & & Uses & Resources & Uses & Resources & Uses & Resources & Uses & Resources & Uses & Resources & Uses & Resources & Uses & Resources & Resources & Uses \\
\hline \multirow{2}{*}{$\begin{array}{l}\text { Secondary } \\
\text { distribution } \\
\text { of income } \\
\text { account }\end{array}$} & $\begin{array}{l}\text { B5n Balance of primary } \\
\text { income, net/National } \\
\text { income, net }\end{array}$ & & & & & & & & 100 & & -100 & & 0 & & & & \\
\hline & $\begin{array}{l}\text { B6n Disposable } \\
\text { income, net/NDP, net }\end{array}$ & & & & & & & 100 & & -100 & & 0 & & & & & \\
\hline \multirow{3}{*}{$\begin{array}{l}\text { Use of } \\
\text { disposable } \\
\text { income } \\
\text { account }\end{array}$} & $\begin{array}{l}\text { B6n Disposable } \\
\text { income, net/NDP, net }\end{array}$ & & & & & & & & 100 & & -100 & & 0 & & & & \\
\hline & $\begin{array}{l}\text { P3 Final consumption } \\
\text { expenditure }\end{array}$ & & & & & & & & & 0 & & 0 & & & & & 0 \\
\hline & $\begin{array}{l}\text { B8n Saving, net/ } \\
\text { National saving, net }\end{array}$ & & & & & & & 100 & & -100 & & 0 & & & & & \\
\hline \multirow[t]{2}{*}{ Accounts } & \multirow[t]{2}{*}{ Concepts } & \multicolumn{2}{|c|}{ Central bank } & \multicolumn{2}{|c|}{$\begin{array}{l}\text { Deposit-taking } \\
\text { corporations }\end{array}$} & \multicolumn{2}{|c|}{$\begin{array}{l}\text { Non-financial } \\
\text { corporations }\end{array}$} & \multicolumn{2}{|c|}{ Households } & \multicolumn{2}{|c|}{ General government } & \multicolumn{2}{|c|}{ Total economy } & \multicolumn{2}{|c|}{ Rest of world } & \multicolumn{2}{|c|}{ Goods and services } \\
\hline & & Applications & Origins & Applications & $s$ Origins & Applications & Origins & Applications & Origins & Applications & Origins & Applications & Origins & Applications & $s$ Origins & Resources & Uses \\
\hline \multirow[t]{2}{*}{$\begin{array}{l}\text { Capital } \\
\text { account }\end{array}$} & $\begin{array}{l}\text { B8n Saving, net/ } \\
\text { National saving, net }\end{array}$ & & & & & & & & 100 & & -100 & & 0 & & & & \\
\hline & $\begin{array}{l}\text { B9 Net lending/ } \\
\text { net borrowing }\end{array}$ & & & & & & & 100 & & -100 & & 0 & & & & & \\
\hline \multirow[t]{4}{*}{$\begin{array}{l}\text { Financial } \\
\text { account }\end{array}$} & $\begin{array}{l}\text { B9 Net lending/ } \\
\text { net borrowing }\end{array}$ & & & & & & & & 100 & & -100 & & 0 & & & & \\
\hline & $\begin{array}{l}\text { F22 Government } \\
\text { current account } \\
\text { deposits in the } \\
\text { central bank }\end{array}$ & & -100 & & & & & & & -100 & & -100 & -100 & & & & \\
\hline & $\begin{array}{l}\text { F22 Households' } \\
\text { accounts in savings } \\
\text { banks }\end{array}$ & & & & 100 & & & 100 & & & & 100 & 100 & & & & \\
\hline & F21 Bank reserves & & 100 & 100 & & & & & & & & 100 & 100 & & & & \\
\hline
\end{tabular}

Source: European Commission and others, System of National Accounts 2008 (ST/ESA/STAT/SER.F/2/Rev.5), New York, 2016 [online] https://unstats.un.org/unsd/nationalaccount/ docs/sna2008.pdf.

a The code used corresponds to the transaction classifications of the System of National Accounts 2008 


\section{Annex 3 \\ How to record government support to employers, self-employed workers and households to mitigate the impact of the COVID-19 pandemic}

Note that the last column reflects the direct impact, all other things being equal, of government support on the main aggregates to the national accounts to mitigate the effects of the reduction in working hours (consequently, it does not reflect the negative impact of the crisis on the operating surplus or mixed income, for example).

Government intervention
1. Government to support employers (private
and public) maintaining their businesses and
keeping their employees on the payroll, with
a view to having a quick return to production.

2. Government to support households to maintain their income, payable as social benefits.

3. Government to support households to maintain their income, not payable as social benefits.

4. Government to support self-employed workers with a view to supporting their business operations

\section{Proposed national accounts recording}

Recorded as other subsidies on production (D39) from the government to the employer and continued payment of remuneration by employer to employees as wages and salaries (D11)

Recorded as social security benefits (D621) or social assistance benefits (D.623) from the government to households, and not as subsidies on production (D39) or continued payment of remuneration in the form of wages and salaries (D11) from employer to employees for the reduced working hours.

Recorded as miscellaneous current transfers (D75) from the government to households, and not as subsidies on production (D39) or continued payment of remuneration in the form of wages and salaries (D11) from employer to employees for the reduced working hours.

Recorded as other subsidies on production (D39) from the government to the self-employed.

\section{Aggregates to the national accounts}

Operating surplus (B2) and mixed income (B3) of employers

Wages and salaries (D11)

Social benefits (D62)

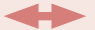

Disposable income (B6) of households<smiles>C1C2CC1C2</smiles>

Saving (B8) of the government

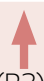

Operating surplus (B2) and mixed income (B3) of employers

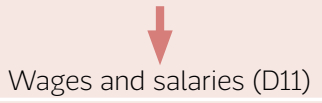

4

Social benefits (D62)

Disposable income (B6) of households

Saving (B8) of the government

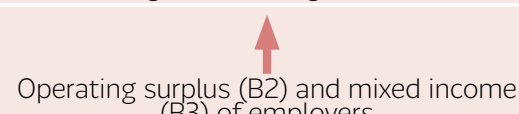

(B3) of employers

1

Wages and salaries (D11)

4

Social benefits [other than social transfers in kind] (D62)

Disposable income (B6) of households<smiles>[C]1C2CC1C2</smiles>

Saving (B8) of the government<smiles>[CH]1[CH]C=C1</smiles>

Mixed income (B3) of households<smiles>C1C2CC1C2</smiles>

Disposable income (B6) of households

Saving (B8) of the government

Source: Economic Commission for Latin America and the Caribbean (ECLAC), on the basis of Eurostat; International Monetary Fund (IMF); Organization for Economic Cooperation and Development (OECD) and United Nations, "COVID-19: How to Record Government Support to Employers, Selfemployed and Households. Statistical Advice", 2020 [online] https://statswiki.unece.org/download/attachments/278038679/Recording\%20 of\%20government\%20support\%20to\%20employers\%20and\%20self-employed. pdf?version=2\&modificationDate=1587380197615\&api=v2 . 
This document is part of a series of reports prepared by the Economic Commission for Latin America and the Caribbean (ECLAC) on the evolution and effects of the COVID-19 pandemic in Latin America and the Caribbean. It was prepared by the Statistics Division, directed by Rolando Ocampo, under the general coordination of Alicia Bárcena, Executive Secretary of ECLAC.

Copyright (C) United Nations, 2020 